\title{
The Bible as seedbed for revival in the 21st century
}

\section{Author:}

Johannes M. Wessels ${ }^{1}$ (I)

\section{Affiliation:}

${ }^{1}$ The Unit for Reformational Theology and the Development of the South African Society, Faculty of Theology, North West University, Potchefstroom, South Africa

Corresponding author: Johannes M. Wessels, morutijo@gmail.com

Dates:

Received: 03 Dec. 2019

Accepted: 22 May 2020

Published: 05 Aug. 2020

How to cite this article: Wessels, J.M., 2020, 'The Bible as seedbed for revival in the 21st century', In die Skriflig 54(2), a2584. https:// doi.org/10.4102/ids. v54i2.2584

\section{Copyright:}

(C) 2020. The Authors. Licensee: AOSIS. This work is licensed under the Creative Commons Attribution License.
One of the key slogans of the Reformation is ecclesia reformata semper reformanda [a reformed church should always be reforming]. The constant reformation and renewal of the church always was, and still is, a key factor in the longevity of the church in changing and different contexts. Often in history, the church has been in danger of falling back so much on tradition that it did not grasp the concept of getting out of its rut and into the groove of God's movement in the world. In a sense, this problem is because of a perceived dichotomy between the principle of sola scriptura, which views the Bible as an immovable point of reference, and following the guidance of the Spirit towards the continuous awakening and revival of the church. Recent studies on revival over the centuries have shown how lasting revival always has the Word and the distribution thereof as an important point of departure. This article focuses on the role of the Word in revival, and contemporary methods of speeding up translation and distribution of the Word.

Keywords: Bible; 2 Timothy 3:16; Sola scriptura; Pentecostalism; Reformed; Revival; Ecclesia reformata semper reformanda.

\section{Introduction}

The emergence of Protestantism is undoubtedly one of the most important shifts within the body of the New Testament Church. Historians would describe it as a part of the Enlightenment in the age of science, where the hierarchy of the church was challenged in many ways. Through this movement, the Bible as the Word of God and its proclamation were restored to the sphere of the laity opposing the strong hierarchy that existed in the church of the day.

Based not only on the enthusiasm and energy that came forth from this movement, but also on the resistance that it encountered, this could be described as a true revival event in history. Sadly, however, the church has often forgotten how it is rooted in revival, and depends on the principle of ecclesia reformata semper reformanda [a reformed church should always be reforming] to evade the same pitfalls that contributed to its emergence and existence. The author intends to show how an approach where the adherence to the inspiration of the Canon can combine with Revivalism to form a strong but lasting impact amongst all nations. The aim is to assess the previous and current views on Revivalism as a phenomenon within Evangelical reformation and Pentecostalism, as well as the consideration of translation methods to improve the availability of the Bible as the Word of God to all. This focus on the distribution and establishment of the Word is being presented as a unifying project within the broader church and revival movements.

\section{Protestantism, Pentecostalism and Revivalism} The ever-present 'split' during and after the Reformation

The view of the Reformation around the 16th century as a revival from within the Roman Catholic Church is widely recognised (Buys 2008:165-166). One of the less known and sad sides of the revival is the way in which this reformation also lacked unity, to the point where the Anabaptists were persecuted by the emerging leaders of the Reformation and Catholics (Lehmann 2017:19). One clear indication of this persecution is the way in which Martin Luther himself, being persecuted by the Roman Catholic Church, approved the persecution and execution of Anabaptists proposed by Melanchthon (Van de Vliet 2017:1).

In an age where there is a growing tolerance between Reformed and Pentecostal churches, this history still remains as an 'elephant in the room', a point of discussion that is often evaded for the

Note: Special Collection: Impact of Reformed Theology. 
sake of unity. ${ }^{1}$ Through centuries of academic endeavours, there was often the view that Pentecostals evaded the labour of deep study into the Word of God using the concept of 'being led by the Spirit' as a cop-out, whilst Pentecostals would criticise Reformed churches of their lack of sensitivity towards the baptism, movement and direction of the Holy Spirit (Wiarda 2017:240).

In his discussion of the relation between Luther and the 'radical reformers' or Anabaptists, Lehmann (2017) states that 'just as Luther claimed direct access to the true meaning of God's word, ...' anyone else was able to:

$[R]$ ead the Bible and draw conclusions. He incurs that Luther's 'unruly offspring' drew conclusions on Christian communities and the secular world, and that they did not hesitate to challenge the Wittenberg professor... (p. 18)

when they disagreed with him.

Even though it must be acknowledged that the Anabaptist movement during the Reformation was a movement that cannot be equated to Pentecostalism of the 21st century, it is important to realise that there are major similarities. The role of the 'second' baptism, as the name Anabaptist refers to in Greek, is often a serious concern and often viewed as a valid reason for suspending or even terminating membership of a Reformed Church in the context of the modern church.

The second major aspect of resemblance is the more direct or proof-text interpretation and application of the Scripture, with a resistance of 'spiritualising' and 'abstracting' the intention and meaning of certain Biblical texts (Lehmann 2017:19). Amongst the other resemblances is the tendency that Anabaptists in the 16th century and Pentecostals today often come from the poorer masses, rather than the rich elite of society (Lehmann 2017:20). Despite the emergence of prosperity theology as a branch of Pentecostalism over the past 20 years, many Pentecostal churches exist in situations of utter poverty, with very little structures or buildings to their disposal. This was also the case in the early years of the Anabaptists, where many of the believers were living very basic lives because of their literal adherence to the texts in Acts 2:42-47 and 4:32-37.

\section{Revival in African contexts}

Revivalism in the continent of Africa is often connected to the Azusa street revival in Los Angeles, and the subsequent visit of John G. Lake to South Africa around 1910. This revival is seen as the root of not only the Apostolic Faith Mission in South Africa but also of the Zion Christian Church. The revival in the Wellington-Paarl area in the 1860s during the ministry of Andrew Murray and G.W. Van der Lingen (Hammond 2014:1) was actually further back, although not as far reaching in nature.

1.In his book, Counterfeit Revival, Hanegraf (1997:14) states that many of the leaders of radical covinal movements falsely view the revisals under their leadership as in line with the Great Awakening that started under Jahn Ed 列 Hanegraaff, however, clearly points out the difference in approaches on several aspects.
The revival in Wellington is still 'commemorated' or 'celebrated' in the Dutch Reformed Church by having a yearly 'week of Pentecost', with services focused on the work, gifts and fruits of the Holy Spirit. This revival is still viewed 'as a true Christian spirituality', being 'faithful to the contemporary spirituality of the Dutch Reformed Church of South Africa' (Lee 2006:x).

These revivals mainly took place in a context where there was a widespread availability of God's Word, as well as opportunities for educating church leaders and members. In the wake of these revivals came other movements such as the revival of Reinhard Bonnke, the revival amongst the Zulus led by Erlo Stegen ${ }^{2}$ and even current revival movements by persons such as Dag Heward Mills and Angus Buchan. Just as in the time of the early reformers, revival preachers still create a stir amongst academics, mostly labelling them as uneducated lay preachers with a shallow theology. It is evident that in many ways the central force of the Reformation is still held captive by the neoScholasticism, which gained momentum after the death of Calvin (Taljaard 1976:192).

Even though Pentecostal theology initially lacked a large body of academic researchers because of its renouncing of a scholastic, intellectual theology, this is surely changing since the turn of the century. In an article entitled 'Father, son, and holy scriptures?', Sawyer (2005:1) highlights a continuing problem in the mainstream evangelical academic or theological community. He describes it as an ongoing rationalism that seeks ultimate certainty and assurance of its knowledge in the objective 'facts' of the Scripture rather than formally recognising the existential dynamics of the Holy Spirit in the life of the believer.

Despite this remaining 'split', several factors have contributed towards a shift in the ecumenical and academic tolerance. Firstly, the shift in views of the inspiration and relevance of the Scripture for present-day churches has led to new alliances that were previously unimaginable. One such example is the move towards closer cooperation between the Reformed churches of South Africa and the Apostolic Faith Mission. The Apostolic Faith Mission has affiliated its theological training to the North West University, mainly because of important theological considerations, of which the views on the inspiration and nature of the Scripture are paramount (Nel \& Van Rensburg 2016:8). This does prepare the soil for reconciliation, growth and academic excellence in understanding the need for constant renewal and revival, with a solid use of Scripture as a strong, ever-present basis.

2.The revival amongst the Zulus started in 1966, where Stegen and his congregants experienced the outpouring of the Holy Spirit in an experience similar to Acts 2. The revival was charterised by people coming to the ministry looking for Aeliverance, revival was char octerised by people coming to the mistry looking for deliverance, people confessing their sins as well as many miracle healings that took place (Stegen
1998:25).

3.Scholars, such as Lehmann (2017:17), describe how Luther translated the Bible into German, making it accessible to everybody, but later insisted on formal education German, making it accessible to everybody, but later insisted on formal education
for anybody preaching the Word. According to Lehman, this was a shift back to the for anybody preaching the Word. According to Lehman, this
same Scholasticism against which Luther had advocated. 
The movement towards the theological 'mapping' of revival theology within the broader theological sphere is also evident in the work and endeavours of Keener (2011). Initially originating from an agnostic background, Keener (2011) wrote a work in two volumes of miracles, with scientific proof that miracles still happen in the modern-day church. Keener's work is especially important in the light of the fact that several proponents of the principle of sola scriptura uphold Cessationism as an answer to the lack of the gifts of the Holy Spirit in their faith communities.

The emergence of the organisation of South African house church congregations under the scholar Christo Nel (2019) is an added testimony of the different structures in which the revival movement is forming in South Africa. This does not necessarily involve new structures or churches but a 'return' to the fivefold ministry and disciple-making processes from which the modern church have evolved over time. Revival in the context of the house church movement would comprise a movement away from large gatherings but focusing on transformation through discipleship and mutual care in the same way as done by the apostles in Acts 2 and 4.

Even though he is definitely not classified as a Pentecostal, the work done by Alan Hirsh on the fivefold ministry versus the reigning pastor-flock model is also significant in this regard. In his book Forgotten Ways, Hirsh (2006) advocates a 'Back to the Bible' movement in terms of church structure and evangelism, which is groundbreaking in comparison to currently held beliefs.

\section{Revivalism as a return to sola sacra (spiritus et) scriptura}

In the course of history, the Revival movement was often equated to radicalism, just as the titles of two works on Luther and the Anabaptists confirm (cf. Gish 1969; Heal 2017). The concept of radicalism has undergone a full pendulum swing in its history. The etymology of the word clearly constitutes something very 'fundamental' about the concept. Even though fundamentalism ${ }^{4}$ and radicalism would oppose each other in most contexts, the etymological roots of these words are very similar in meaning. Initially, radicalism would refer to those who would value the 'root', or 'foundation', of an institution, organisation or movement, and do everything in their power to re-establish the initial goals or calling of such an institution, organisation or movement. Often in history, such a return to the roots could only be achieved by overthrowing the existing structure. This resulted in radicalism acquiring a negative or even revolutionary sense to it.

However, not all scientists and researchers have thrown the baby out with the bathwater. Even the 20th century one's own understanding is equated to the enlightenment of the Holy Spirit (Janse van Rensburg et al. 2015:319). publications by Mekkes (1971) and Robinson (1971), as well as Taljaard (1976), view positive movement towards a radical right, which would be described as a radical Biblical pattern of thought (Taljaard 1976:193). It is important to recognise the insight of Mekkes (1971:213) that radicalism is in its essence often not a conscious move of the mind but involves emotional passion that stems from the heart. Gish (1969:30) distinguishes liberalism as negative and radicalism as positive. He even states that being a Christian means being a radical (1969:79).

Recently, dictionaries have indicated the positive move and appreciation of the word 'radical' by the youth of our era. 'That's radical!' would often be an appraisal of something performed with extraordinary skill or talent. It is important to realise that this positive meaning of 'radical' is surely making its way back into theological language, with terms such as radical discipleship, radical obedience and radical surrender becoming more and more common.

Over the years, several studies have shown how a Revival movement has a negative side to it, and may even promote heresy and blasphemism (Buys 2008; Hanegraaff 1997; Moga 2019; Visser 2014). In a well-documented study, Counterfeit Revival, Hanegraaff (1997:47-57, 125-130) points to the pitfalls and character of several of the revival movements (and leaders), such as the Toronto Blessing and the Azusa Street Revival.

The split between the 'orthodox reformation' and the 'radical reformation (Anabaptism)' in the form of Pentecostalism and its various descendants is actually much smaller than often perceived. Heal $(2017: 10,11)$ suggests that

'Scholars should adopt an open-ended understanding of evangelical reform, and recognize that the boundaries between radicalism and its opposites (the magisterial reformations, the confessional churches, orthodoxy) were not firmly drawn.'

The additional themes of radical prayer, radical worship and radical healing are strange and even disturbing to the traditional reformed ear. However, important academic collaboration is necessary to realise how these expressions of the passion and the gifts of the Holy Spirit are not foreign to the Word, but must flow from the continuous inspiration of the Spirit as author in our lives.

Currently, Revivalism is often linked to the idea that the church is busy writing Acts 29. This can raise the eyebrows seriously in terms of the closing of the Canon, and the seeming presumptuousness of the church within revival theology. Being viewed in the right light, this concept might give birth to an important hermeneutical point of departure regarding the role and function of the church in the 21st century, as well as the doctrine on the cessation of the apostolic era.

If this understanding of the activity of the church (writing Acts 29) is interpreted as a genuine effort to continue in the 
footsteps of Jesus and his apostles, it could yield wonderful results, not as much academically but motivating the church to persist in radical, relentless mission to reach the ends of the earth... This view can contribute to trusting the Holy Spirit to work in the lives of believers through special gifts, such as speaking in tongues, driving out demons and performing miracles, and bringing them to Jesus, their Lord and Saviour.

\section{The same Bible, different approaches \\ The exegesis and application of the Bible as seedbed for revival}

During the Reformation, the Anabaptists portrayed a wide array of opinions regarding the authority of Scripture. Some circles rejected the revelation in the Old Testament, whilst others showed an almost legalistic following of Old Testament laws. In a groundbreaking book on South African Pentecostalism, Nel (2017) demonstrates how Pentecostalism has outlived the criticism of detaching inspiration from the Scripture and blindly following the leading of the Holy Spirit according to everyone's random perception.

From being perceived as further away from the sola scriptura belief than most of Christianity, the increasing infiltration of liberalism within theological circles has resulted in a scenario where the Pentecostals are closer to the sola scriptura principle than many Reformed churches of the current theological scenario.

Although there have been big differences in hermeneutics and the interpretation of the Scripture, as well as in the cessation of gifts, the role of the Holy Spirit in interpretation and preaching has always remained very prominent in reformed, evangelical and Pentecostal circles. In contrast to many other current exegetical approaches, the guide Conceiving a Sermon (Janse van Rensburg et al. 2015) prioritises prayer to the Holy Spirit for interpreting the text as the first step in reformed exegesis.

In essence, Pentecostal exegesis differs from the traditional Reformed criterion in its priorities but not necessarily in its aims. It has already been stated that the role of prayer and seeking the guidance of the Holy Spirit is a primary focus to attain a valid exegesis. In the exegetical approach used by Janse van Rensburg et al. (2015:16-18), several additional aspects have been highlighted. These are the consideration of literary aspects, including time of origin of a book, distinction between time-bound and time directedness of the text, sophisticated utilisation of other sources, caution for being a naïve reader and allowing the Scripture to be its own interpreter.

Nel (2017) summed up the following as the three main aspects of Pentecostal exegesis:

1. Reading the Bible to find a way to have a personal encounter with God.
2. The awareness that the Scripture is the product of an experience with the Holy Spirit.

3. An apostolic witness can only be truly understood if it is experienced in an existential manner.

In assessing the above, ${ }^{5}$ it is probably the last aspect that may evoke the most debate, as it concerns the cessation of the apostolic era and the accompanying special gifts of the Holy Spirit. It is also true that reformers, such as Calvin, have advocated the importance of a lifestyle of faith according to the Word in opposition to a Scholastic dualism as found in the Roman Catholic Church.

It is important that over and above the high regard that the Pentecostals hold for the gospel, the hermeneutical approach also portrays a sincere intention to understand and apply the Word in the life of the believer through the help and mediation of the Holy Spirit (Nel 2015:1).

Other than just the views on the inspiration and hermeneutics of the Scripture, the use (or lack thereof) of the Bible during revival meetings has always been a concern. Pentecostals are often viewed to apply the Scripture with little or no significance placed on the original context (Hanegraaff 1997:183-196). It is, however, true that the Word is frequently accompanied by the giving of testimonies that God is still working miracles in the present as found in biblical narratives (Fogarty 2015:5).

The author recalls a revival service where the sinner was compared to the donkey that was fastened in the town of Jerusalem, and that Jesus sent his disciples to call him up to higher duty. Before the donkey was freed, he only had access to a small area of grass, but after his release, he had access to the fields out there. It is clear that a proof-text method of approaching this Scripture is not acceptable, and that it may lead to serious fallacies in applying the Scripture in the life of a believer.

Greater than the danger of putting the Bible in the hands of every believer and preacher is the lack of availability of the Bible at all. Access to the Bible in many Eastern and Middle Eastern nations is still a big concern, even though the digital era has provided alternatives in bringing God's Word to the people (Franklin \& Niemandt 2013:6).

In the southern African post-colonial context, there has certainly been a decline in the impetus towards the distribution of Bibles, as the mainline churches have lost much of their political influence, as well as members, because of a rise in secularism and Pentecostalism. As the distribution of the Bible was always a great priority in mainline Protestantism, the revival movement seemed to move into new areas with great force without the availability of the Bible in those languages or areas.

5.In comparing the two exegetic approaches, it is clear that Pentecostal exegesis is much more interested in the outcome of the exegesis for ordinary life rather than much more interested in the outcome of the exegesis for ordinary life rather than
the process itself. This does have the danger of reading the text out of context and misinterpreting the message of the text. 


\section{Understanding the need for Bible translation and distribution as preparation for revival}

The mission fields in Africa are strewn with white elephants having impressive buildings and structures that were erected with great enthusiasm without the necessary backing in training, staffing and sustainability. Research has shown that revival without the availability of the Scripture lacked impact in societies (Berding 2014). Areas where revivals have been conducted without the availability of the Scripture to do the follow-up have shown to have only $2 \%$ of the converts still following Christ after two years.

The lack of Scripture as the pre-planting agent ${ }^{6}$ has several problems. Firstly, such a church can easily be built upon charismatic leadership, and it falls away easily when such a leadership either withdraws or develops conflict within the faith community. Secondly, people often become immunised and build up a resistance against the gospel when there is just enough to interest them without a substantial foundation and growth agent.

So what has happened in situations where revival and evangelism have been preceded by the availability of the Bible? Practical experience has shown results in India, where the church has grown by $240 \%$ after two years of fostering revival by focusing on edifying the new converts in Bible schools (Dyer 1900). A similar example is referred to by Cairns (1986:196-197), who describes the Walsh revivals of 1859 and 1904. The revival of 1959 was undergirded by focusing on the Word and Bible study, and had a long-term impact on the country. On the contrary, the earlier revival led by Roberts did not focus on the Word and the study thereof. The result was that the 1904 revival was short-lived. According to Cunningham (2017:23), '[t] missionaries showed in black and white that God's word enables people to live for Christ'.

A further development in the 20th century was the focus on radical discipleship. One of the emerging movements in southern Africa was the Discipleship making movement (Watson 2012:22-26). The key drive in this movement was to bring people to Christ through friendship evangelisation and the formation of small groups. At the core of the small group meetings was a Discovery Bible Study time, during which the Scripture was read, studied and discussed (Mendola 2016:1). This movement is interdenominational and is growing rapidly, bringing many people to Christ and shaping their lives as disciples of Jesus.

The above statistics clearly show how honouring the sola scriptura principle can lead the converts of revival to a point where it is able to really saturate communities and societies with followers of Christ whose lives have changed permanently. The statistics also show how the broad spectrum of reformed theology must strategise towards maximum efficiency in ending Bible poverty when it comes to the evangelisation of the world.

6.'Pre-planting' is a term borrowed from agriculture, where fertiliser is put in the ground well before the actual seeds are sown.
The sola scriptura principle during the Reformation was probably still coloured with a strong sense of supervision in reading and interpreting the Scripture, especially in the wake of neo-Scholasticism. When funds were easily available in the past, translation of the Bible was a priority.

Because of several reasons, this momentum has changed. Gravelle (2015:1) has mentioned several reasons for this. He states that the focus has often been on church planting, rather than on Bible translation. There is a wrong perception on what the translation process involves. He further argues that Bible translation is a theoretical and scientific task that takes many years to complete, and that Bible translation is considered to be the work of foreign linguists and biblical language scholars.

Because of the diminishing numbers of mainline churches in southern Africa, the support of missionaries doing translation work and the support for translation projects have been definitely affected. In several countries, it has been more and more difficult to acquire work permits for the prolonged stay of translators. In a study conducted on the Bible Society of South Africa, Sieberhagen (2007:194) shows how the distribution of Bibles through schools and churches had dropped from 285032 in 1994 to 6936 in 1999. Therefore, it is clear that a new motivation is needed to stress the importance of Bible translation and distribution in the South African society.

\section{Remarks on 2 Timothy 3:16-17 as a locus classicus in view of the Scripture}

In view of the theme and preceding discussion on sola scriptura as an important departure point for the church in the 21st century, a few practical comments on this locus classicus in the view of the Scripture and the Canon are made alongside an interpretation in the light of the Pentecostal approach to exegesis. For the sake of reference, the text is provided in Greek, as well as in the New International Version (NIV) translation:

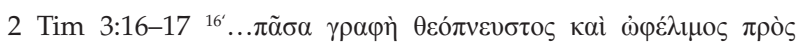

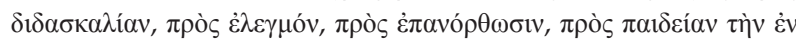

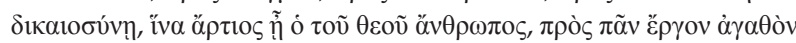

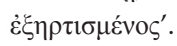

2 Tim 3:16-17 ${ }^{16^{\prime}}$ All Scripture is God-breathed and is useful for teaching, rebuking, correcting and training in righteousness, ${ }^{17} \mathrm{so}$ that the servant of God may be thoroughly equipped for every good work'.

The current forms in which the Scripture has been made available to us does place it as being ' $\theta \varepsilon$ ó $\pi v \varepsilon v \sigma \tau o \varsigma^{\prime}$ ', or Godbreathed $^{7}$ (a hapax legomenon) in a new light. The respect for the Bible as a physical book has traditionally bordered the respect and reverence that the Muslims have for the Koran as a physical book. The inspirational nature of the Scripture would also be relevant in the sense that God is continuously inspiring his children through the Holy Spirit to look at new and creative ways to give his words wings to spread to all nations.

7.De Boer (2019) gives a thorough explanation of the context in which God-breath is used here. 
Secondly, the meaning of the above-mentioned verse could also be seen in its full impact when viewed from a reverse angle. This would mean that without the presence of the Scripture in an area, there would be little content for teaching and for knowing the character of the Triune God. The gospel would be strangled by many false and selfish teachings, without proper ground for rebuke or correction. Without the guidance of the Scripture, there would be an empty religion without character or righteousness, and believers would be poorly equipped for doing good or going out to spread the gospel further.

To the Revivalist or Pentecostal who takes inspiration from the Scripture seriously, the Word of God would always provide the ground or basis for a closer relationship with him, because being God-breathed means that the Scripture is alive with the breath and Spirit of God, and that intentional interaction with the Scripture by new converts will provide the basis for growing in an intimate relationship with God.

This text is also the basis for the Pentecostal point of departure that the Scripture is the 'product of an experience with the Holy Spirit'. This means that new believers can be expectant of the Spirit's revelation as they take up and read the Bible, and that they can be touched and affected by the richness and wisdom the Scripture radiates.

Lastly, the above verse calls for being applied and adhered to by believers. Even the young believer is called to teach and instruct new believers in righteousness, to bring into line dissidents from the Word and its message, and to equip new disciples for good work in the kingdom of God. It is especially in this area where the Discovery Bible Study does not only discuss the Biblical text but also draws students towards finding practical applications of the Scripture in their lives, and requiring feedback on the transformation that a specific Scripture brought in their lives.

\section{Ending Bible poverty now...}

There are currently about 4100 languages in which the Bible has not been translated yet, and these must be seen as a task of high priority. In the quest to end Bible poverty, Cunningham (2017) provides a few basic strategies. As a point of departure, he emphasises prayer as the most important aspect. He pleads for a new focus on the translation of the Bible in written and verbal forms, as well as the production and distribution of these translations. Lastly, he emphasises education and engagement with the Word in these unreached communities.

\section{The relationship between Bible poverty and poverty as a general phenomenon}

When it comes to the Biblical calling to bring the gospel (in its different translations) to the poor, statistics show that ending Bible poverty has not always been the highest priority. It has been shown that the church often leans towards serving and pleasing the haves, whilst the have-nots are to be satisfied with the crumbs from the table (Wessels 2010).

The efforts in Bible translation are no different. In the United States of America, there are more than 500 English translations of the Bible (Peterson 2013:1), whilst there are still more than 2000 languages in which no Bible translation project has been initiated. Currently, there are 10 translations in the Afrikaans language. There are very few (besides English) other language groups in southern Africa with more than two translations at their disposal. Also, there are about 30 groups in southern Africa with no Bible in their vernacular language (BPI Infographics 2020:1-45).

Although the servant of the Lord is anointed (Is 61:1) and appointed by the Holy Spirit to bring the good news to the poor, Bible societies are also often bound by the prescriptions of donors to decide the languages into which translation work would be carried out. In an effort to focus on the translation process, the Wycliffe Bible Translators International (1999:5; later renamed as WGA) envisioned at their congress in 1999 to have a Bible translation project '.. in progress for every people group that needs it...' by 2025 .

The mission to end Bible poverty has to be accompanied by a sincere effort to bring the gospel as well as the Bible itself to nations and cultures in different and difficult-to-reach countries. Together with new translation methods, the quest to bring the Word to every nation and language under the sun will need serious efforts towards marketing and recruiting donors. Peterson (2013:1) expresses this well as he states that '...there's more to poverty than meets the eye...' and that '... lasting change ... need spiritual solutions that only God's Word in their own language can offer'.

Today, 20 years down the line, it seems as if vision 2025 is not going to be fulfilled. The initial timeline did not really take the context of the third world countries into consideration, which resulted in delays to the original schedule (Franklin \& Niemandt 2013:2-3). Especially the continuing decolonisation of Africa (and other continents) has resulted in a reduced number of missionaries and translators in crucial areas for Bible translation.

\section{Mobilized Assistance Supporting Translation - A new approach to Bible translation}

One of the important developments in the translation field is the Mobilized Assistance Supporting Translation (MAST) programme under Wycliffe Associates. ${ }^{8}$ It is one of the important approaches used to speed up the eradication of Bible poverty (Price \& Gervais 2017:1). In almost a Septuagint fashion, a workshop is held for approximately 10 days, with around 30 or more local translators. These translators are volunteers recruited by church leaders and are all indigenous speakers of the language in question.

8.It is important to note that Wycliffe Associates has no relation to the Wycliffe Global Association, other than the referral to the Reformer John Wycliffe. 
The translation training and process is guided by a qualified exegete, whilst the project values continuous feedback as an important component of successful translation. In an effective workshop, it is often possible to translate the complete New Testament during the period of the workshop, and having the Old Testament translated within a few months.

Depending on the country and training facilities, such a project costs around R100 000 per language. This is a fraction of what traditional translation would cost. Because the translators are all volunteers, their motivation and effectiveness are vastly different from paid workers, who would often prolong the process for financial gain. These translations are made available immediately within a the Internet and are accessible to the public.

What is significant about these translation projects is the fact that a theologically conservative association such as Wycliffe also uses translators and missionaries from Revivalist and/ or Pentecostal orientation, as they are prepared to work anywhere and even under difficult circumstances.

The MAST method has evoked criticism (Zylstra 2015), often from other translation organisations, which need to explain why their work takes much longer time. Initially, the quality of this process will not always be equal to traditional translations, but the digital publication of the translation, together with an extensive review process, will surely iron out initial errors.

Despite the fact that it has attracted criticism, it is clear that the MAST programme contributes largely towards reducing the number of language groups that do not have access to the Bible in their own dialect.

Understanding the importance of the Bible as the seedbed for revival would also mean that there should be a focus on linking or communicating the areas where new translations are available to mission organisations. This could result in a more effective focus and ministry to areas where the seedbed for revival is prepared, and lasting results in terms of discipleship could be achieved.

\section{Conclusion}

In a rapidly changing society, the principles of sola scriptura and ecclesia reformata semper reformanda surely have the potential to unite rather than divide. However, all this begins with a re-evaluation and perhaps even a re-categorisation of the participants within the Reformation. From the evidence presented in this article, it is clear that the Pentecostals have never really viewed themselves as non-reformed or reforming.

It is clear that the world out there is hunger for the church to join hands towards bringing an end to Bible poverty and creating an atmosphere in which true discipleship can blossom. The time has come to look less past the beam in our own eye than towards the splint in our fellow Christian's eye. It is time to work with a common ground towards taking more ground for the kingdom.

To achieve this, the core aspects of the Reformation need to be celebrated, especially the celebration of the Word as the only guideline for our faith. May we receive the grace to foster such openness, and see how God establishes his kingdom until the ends of the earth, making disciples effectively!

\section{Acknowledgements Competing interests}

The author declares that he has no financial or personal relationships that may have inappropriately influenced him in writing this article.

\section{Author's contributions}

J.M.W. is the sole author of this research article.

\section{Ethical considerations}

This article followed all ethical standards for research without direct contact with human or animal subjects.

\section{Funding information}

This research received no specific grant from any funding agency in the public, commercial or not-for-profit sectors.

\section{Data availability statement}

Data sharing is not applicable to this article as no new data were created or analysed in this study.

\section{Disclaimer}

The views and opinions expressed in this article are those of the author and do not necessarily reflect the official policy or position of any affiliated agency of the author.

\section{References}

Berding, K., 2014, Bible revival: Recommitting ourselves to one book, Faithlife Corporation, Bellingham, WA.

BPI Infographics, 2020, Bible poverty index, viewed 13 April 2020, from https:// uploads-ssl.webflow.com/5a0a59f45f389a000169e41a/5a2b44f09ef2d6000152 6bdb_BiblePovertyIndex.pdf.

Buys, P., 2008, 'Reformation and revival', Haddington House Journal 10(1), 163-192.

Cairns, C.E., 1986, An endless line of splendor: Revivals and their leaders from the great awakening to the present, Tyndale, Wheaton, IL.

Cunningham, L., 2017, We can end Bible poverty now, YWAM Publishing, Seattle, WA.

De Boer, E.A., 2019, 'Spirit and scripture: From Theopneustos through Inspiratus to God-spirited', in G. Van den Brink, E. Van Staalduine Sulman \& M. Wisse (eds.), The spirit is moving: New pathways in pneumatology, pp. 64-76, Brill, Leiden.

Dyer, H.S., 1900, Pandita Ramabai: The story of her life, Revell, New York, NY.

Fogarty, S., 2015, 'Toward a Pentecostal hermeneutic', Pentecostal Charismatic Bible Colleges 5(2).

Franklin, K.J. \& Niemandt, C.J.P., 2013, 'Vision 2025 and the Bible translation movement', HTS Theological Studies 69(1), Art. \#1332, 8 pages. https://doi. org/10.4102/hts.v69i1.1332

Gish, A.G., 1969, The new left and Christian radicalism, Eerdmans, Grand Rapids, MI. 
Gravelle, G., 2015, Bible translation in the digital age, viewed 28 March 2020, from https://www.missionfrontiers.org/issue/article/bible-translation-in-the-digital-age.

Hammond, P., 2014, Andrew Murray and the 1860 revival at the Cape, viewed 28 March, from https://www.christianaction.org.za/index.php/articles/ revival/781-andrew-murray-and-the-1860-revival-in-the-cape.

Hanegraaff, H., 1997, Counterfeit revival, Word Publishing, Dallas, TX.

Heal, B., 2017, 'Introduction', in B. Heal \& A. Kremers (eds.), Radicalism and dissent in the world of protestant reform, pp. 8-14, Vandenhoek \& Ruprecht, Göttingen.

Hirsch, A., 2006, The forgotten ways: Reactivating the missional church, Brazos Press, Ada, MI

Janse van Rensburg, J., De Klerk, B.J., De Wet, F.W., Lamprecht, A., Nel, M. \& Vergeer, W., 2015, Conceiving a sermon: From exegesis to delivery, Potchefstroom Theological Publications, Potchefstroom.

Keener, C.S., 2011, Miracles: The credibility of New Testament accounts, 2 Vols, Baker Academic, Grand Rapids, MI.

Lee, H., 2006, Spirituality of Andrew Murray Jr. (1828-1917). A theological-critical assessment, viewed 10 March 2020, from http://scholar.ufs.ac.za:8080/xmlui/ bitstream/handle/11660/4797/LeeH.pdf?sequence=1\&isAllowed=y.

Lehmann, H., 2017, 'Martin Luther's unruly offspring: The Protestant reformation and radical critique', in B. Heal \& A. Kremers (eds.), Radicalism and dissent in the world of protestant reform, pp. 15-26, Vandenhoek \& Ruprecht, Göttingen.

Mekkes, J.P.A., 1971, Radix, tijd en kennen, Buiten en Schipperheid, Amsterdam.

Mendola, R., 2016, 'Discovery Bible study: Equipping international students to share Biblical truth around the globe', Mission Frontiers, viewed 20 February 2020, from https://www.missionfrontiers.org/issue/article/discovery-bible-study.

Monga, D., 2019, 'Jonathan Edwards and his theology of revival', Perichoresis 17(1), 55-70. https://doi.org/10.2478/perc-2019-0004

Nel, C., 2019, Ons storie, viewed 15 April 2020, from https://nuwewyn.co.za/new/ wp-content/uploads/2019/04/Boek-Ons-storie.pdf

Nel, M., 2015, 'Attempting to define a Pentecostal hermeneutics', Scriptura 114(1), 1-22. https://doi.org/10.7833/114-0-1044

Nel, M., 2017, He changes times and seasons, Lit Verlag, Münster.

Nel, M. \& Van Rensburg, F.J., 2016, 'Integrating spirituality and rationality the long and arduous journey of the historical development of theological training in the apostolic faith mission of South Africa', In die Skriflig 50(2), a1943. https://doi. org/10.4102/ids.v50i2.1943

Peterson, M., 2013, A different kind of poverty, viewed 08 April 2020, from https:// www.wycliffe.org/blog/posts/a-different-kind-of-poverty.

Price, T. \& Gervais, J., 2017, White paper: MAST, an introduction, viewed 10 April 2020 from https://wycliffeassociates.org/our-impact/translation-strategies/whitepaper-mast-an-introduction/.

Robinson, J.T., 1971, Christelijke vryheid in een tolerante Maatschappij, Uitgeverij Ten Have, Baarn.

Sawyer, M.J., 2005, 'The father, son and holy scriptures?', viewed 20 May 2020, from https://bible.org/seriespage/father-son-and-holy-scriptures.

Sieberhagen, C.F., 2007, 'Die beskikbaarstelling, deur die Bybelgenootskap van SuidAfrika, van die Bybel in die inheemse tale van Suid-Afrika : 'n missiologiese studie', PhD-proefskrif, Universiteit van Pretoria.

Stegen, E., 1998, Revival amongst the Zulus, Kwasisa Bantu Mission, Kranskop.

Taljaard, J.A.L., 1976, 'Radikaaldenke', in Reformasie en Revolusie, pp. 191-210, Instituut vir die bevordering van Calvinisme, Potchefstroom.

Van de Vliet, B., 2017, 'Luther and the anabaptists', Direction Magazine, viewed 10 April 2020, from https://www.researchgate.net/publication/318588830 Luther and the Anabaptists/citation/download.

Visser, T., 2014, Revival and conviction of sin: A quest for God's working in times of spiritual awakening, Christian Liberty Books, Cape Town.

Watson, D., 2012, 'Small groups that have the DNA of a disciple making movement', Mission Frontiers, viewed 05 May 2020, from https://www.missionfrontiers.org/ pdfs/34-6-disciple-making-movement.pdf.

Wessels, J.M., 2010, Offering the gospel adapanon. An interpretation and application of 1Cor.9:18, University of Bamberg, Bamberg.

Wiarda, T., 2017, Spirit and word: Dual testimony in Paul, John and Luke, T\&T Clark, London.

Wycliffe Bible Translators International (WBTI), 1999, Extracts of 1999 WBTI convention, Wycliffe International, Dallas, TX.

Zylstra, S.A., 2015, 'Speedy MAST Bible translation hits a bump', Christianity Today, viewed 10 January 2020, from https://www.christianitytoday.com/ct/2015/ november-web-only/speedy-mast-bible-translation-hits-bump-wycliffe.html. 